\title{
АКТУАЛЬНІ ПРОФЕСІЇ МАЙБУТНЬОГО ДЛЯ МОЛОДІ НА РИНКУ ПРАЦІ УКРАЇНИ
}

\section{CURRENT PROFESSIONS OF THE FUTURE FOR YOUTH ON THE LABOR MARKET OF UKRAINE}

\author{
Стукан Тетяна Миколаївна \\ співробітник, \\ Херсонський державний аграрно-економічний університет \\ ORCID: https://orcid.org/0000-0002-8682-1832
}

Stukan Tetiana

Kherson State Agrarian and Economic University

\begin{abstract}
У статті охарактеризовано основні професії, які створять попит на ринку праці України в XXI столітті. Визначено, що в період карантину серед вікової категорії осіб до 35 років затребуваними стали інтернет-професії: блогер, таргетолог, копірайтер, веб-дизайнер, сторімейкер та візуальщик тощо. Виділено основні чинники, які на сьогодні призвели до популярності інтернет-профресій, хоча вони ще не виведені офріційно на ринок праці, але попит на них зростає з кожним днем. Підтверджено, що виникнення нових просресій розкриває перед молоддю ряд унікальних можливостей для самореалізації та самозайнятості, де це швидко переходять із захоплення в високооплачуваний заробіток. У ході дослідження встановлено, що в Україні залишається поки незмінною тенденція в контексті того, що віковій категорії до 35 років все ж таки легше працевлаштуватися в містах-мільйонниках, де є виробництво, наявна відповідна інфраструктура, а ринок праці більш адаптований під нові зміни професій. Визначений перелік нових професій, які з'являться у зв'язку з зростанням кількості населення на планеті, скороченням ресурсів, збільшенням кількості міст-мегаполісів, погіршенням природно-кліматичного стану та актуальністю альтернативних джерел енергії.
\end{abstract}

Ключові слова: професії майбутнього, ринок праці, молодь, інтернет-профресії.

В статье охарактеризованы основные профессии, которые создадут спрос на ринке труда Украины в XXI веке. Определино, что в период карантина среди возрастной категории лиц до 35 лет затребуваними стали интернет-профессии: блоггер, таргетолог, копирайтер, веб-дизайнер, сторимейкер и визуальщик т.п. Выделены основные факторы, на сегодня которые призвели к популярности интернет-профессий, хотя они пока не виведени офрициально на рынок труда, но спрос на них растет с каждым днем. Подтверждено, что возникновение новых профессий раскрывает перед молодежью ряд уникальных возможностей для самореализации и самозанятости, где это быстро переходит в высокооплачиваемый заработок. В ходе исследования установлено, что в Украине остается пока неизменной тенденция в контексте того, что возрастной категории до 35 лет все же легче трудоустроиться в городах-миллионниках, где есть производство, имеется соответствующая инфраструктура, а рынок труда более адаптирован под новые изменения профессий. Определен перечень новых профессий, которые появятся в связи с ростом численности населения на планете, сокращением ресурсов, увеличением количества городов-мегаполисов, ухудшением природно-климатического состояния и актуальностью альтернативных источников энергии.

Ключевые слова: профессии будущего, рынок труда, молодежь, интернет-профессии.

The article describes the main professions that will create demand in the labor market of Ukraine in the $\mathrm{XXI}$ century. It is determined that during the quarantine period among the age group of persons under 35 years of age, Internet professions became popular: blogger, targetologist, copywriter, web designer, storymaker and visual artist, etc. The main factors that have led to the popularity of Internet professions today, although they have not yet been officially introduced to the labor market, but the demand for them is growing every day. It is confirmed that the emergence of new professions opens up a number of unique opportunities for young people for self-realization and self-employment, where it quickly transitions from a hobby to high-paying earnings. The study found that the trend in Ukraine remains unchanged in the context that it is still easier for people under the age of 35 to find employment in cities with a population of millions, where there is production, appropriate infrastructure and a more adapted labor market. The list of new professions that will appear in connection with the growth of the population on the planet, the reduction of resources, the increase in the number of metropolitan cities, the deterioration of the natural and climatic 
condition and the relevance of alternative energy sources. The labor market in Ukraine today is changing rapidly and each of the subjects should be ready for these changes for both employers and job seekers. Undoubtedly, the labor market is changing due to the development of technology and IT, and thanks to robotics and computerization, some tasks are already performed better than people do. Therefore, starting with the choice of specialty, it is necessary to understand the prospects of employment after graduation, and which of the professions in this period will form a proposal and will be in demand in the labor market and will be able to satisfy the employee with their earnings, career prospects and employer. They also push the professions of the future to the generation under the age of 35 that they should constantly learn throughout life, undergo internships, trainings, business courses, improve their skills so that the skills are relevant and meet the needs of the time.

Keywords: professions of the future, labor market, youth, Internet professions.

Постановка проблеми. Під час світової економічної кризи та в період карантину, який вже триває майже рік діяльність всіх ссрер господарювання зазнала значних трансформацій і більшість стикнулася з тим, що треба шукати нові способи як врятувати свій бізнес від фрінансових втрат. В цьому контексті у ув'язку з переходом на онлайн ринок з реалізації продукції та надання послуг суб'єкти господарювання стикнулися 3 необхідністю перефрорматування діяльності та набуття навичок чи залучення спеціалістів у ссрері сучасних IT-технологій. Тому на ринок праці виводиться ряд нових професій, які направлені на допомогу бізнесу щодо адаптації до умов, які диктує на сьогодні середовище здійснення виробничо-господарської діяльності. Така ситуація зумовлює необхідність молодим фрахівцям здобути відповідні навички та компетентностями в сорері IT-технологій для того, щоб бути конкурентоспроможними на ринку праці в XXI столітті. Популярності також набувають інтернет професії, так як на сьогодні світова мережа поступова входить та повністю захоплює життєвий простір фрізичних та юридичних осіб. Тож актуальним серед молоді $є$ вивчення ринку профресій та їх затребуваності серед роботодавців і якщо бажання й очікування однієї і іншої сторони співпадає, то бажаний есрект отримає кожен.

Аналіз останніх досліджень і публікацій. Вивченням питання зайнятості молоді на ринку праці протягом тривалого часу приділяється значна увага як вітчизняними, так і зарубіжними вченими. В працях А. Оуена, Дж. Кейнса, А. Маршалла, А. Філліпса досліджено загальну проблематику ринку праці та безробіття. Аналіз зайнятості молоді та труднощі їх працевлаштування висвітлені у роботах вітчизняних науковців О. Абашиної, С. Бандури, Д. Богині, О. Большої, О. Грішнової, С. Злупка, О. Кузнєцової, О. Лаврук, Е. Лібанової, В. Онікієнко, В. Петюха, В. Пухлій, В. Савченко та ін. В той же час, постійні зміни в економічному, соціальному, політич- ному житті країни призводять до транссрормацій, в тому числі і на ринку праці в сегменті молодіжної зайнятості в напрямі пошуку затребуваних професій, що спонукає вчених повсякчас досліджувати дане питання і актуальність його не втрачається, а потребує детальнішого вивчення й аналізу.

Формулювання цілей статті. Метою дослідження $є$ здійснення аналізу та обгрунтування переліку професій майбутнього, які будуть затребувані на ринку праці України для вікової категорії від 18 до 35 років.

Виклад основного матеріалу дослідження. Для всіх $€$ очевидним, що пандемія COVID-19 змінила ринок праці як в Україні, так і в цілому світі. Карантин для економічних видів діяльності в країні став поштовхом для позитивних змін та переформатування способу ведення бізнесу з застосуванням новітніх технік і технологій. У зв'язку з чим на ринку праці стали актуальними профресії, які більш адаптовані під молодь і при наявності мінімальних навичок вони можуть легко їх освоїти. Набуття фрахівцями компетентностей в сорері онлайн-технологій та оволодіння процесами діджиталізація є затребуваним, так на сьогодні ми бачимо, що існує попит на webрозробників, програмістів, розробників ігор, аналітиків у ссрері обчислювальної техніки та інформаційної безпеки. Новими профресіями для України в сорері IT, які набиратимуть популярності $€$ архітектор інтернету речей (побутові пристрої, які підключені до інтернету, «розумний будинок»), архітектор віртуальної реальності, проектувальник нейроінтерфейсів, дизайнер аватарів і тестувальник нових технологій. Перелічені професії швидко розвиваються і бізнес зацікавлений в них та вже намагається інтегрувати їх у свою діяльність для того щоб зробити ії̈ більш ефективною. Тож в умовах постійних технологічних змін, трансорормаційних перетворень та становищі в якому опинилось національне господарство під час пандемії на ринку праці з'являється ряд нових профресій (табл. 1). 
Таблиця 1

Профресії, які створять попит на ринку праці України в XXI столітті

\begin{tabular}{|c|c|}
\hline Назва & Характеристика \\
\hline $\begin{array}{l}\text { Менеджер } \\
\text { з антикризового } \\
\text { управління }\end{array}$ & $\begin{array}{l}\text { експерт, який здійснює аналіз діяльності підприємства та визначає його } \\
\text { сильні та слабкі сторони з метою побудови антикризового плану та } \\
\text { фрормування шляхів його реалізації. }\end{array}$ \\
\hline $\begin{array}{l}\text { Експерт із цисррової } \\
\text { трансформації }\end{array}$ & $\begin{array}{l}\text { фрахівець, діяльність якого направлена на допомогу бізнесу стосовно } \\
\text { його переведення } 3 \text { оорлайн режиму в онлайн та визначення } \\
\text { першочергових процесів, які можна перенести із реального } \\
\text { середовища у віртуальне. }\end{array}$ \\
\hline Експерт з BigData & $\begin{array}{l}\text { спеціаліст з оциорування всіх даних наявних у підприємства. } \\
\text { Компанії на сьогодні приділяють максимум уваги для здійснення } \\
\text { обробки накопичених даних для того щоб їх не втратити } \\
\text { і використовувати в подальшому. }\end{array}$ \\
\hline Digital-маркетолог & $\begin{array}{l}\text { це цифрровий маркетинг? просування бренду і залучення клієнтів за } \\
\text { допомогою всіх можливих офлайн каналів: соціальні мережі, інтернет, } \\
\text { е-таil розсилка, контекстна реклама, контент-маркетинг, смс розсилка, } \\
\text { мобільні додатки. Людина даної професії займається комплексним } \\
\text { просування продукту, товару або послуги за допомогою різних видів } \\
\text { маркетингу (онлайн + офрфлайн). }\end{array}$ \\
\hline $\begin{array}{l}\text { Організатор VR/ } \\
\text { AR-трансляцій }\end{array}$ & $\begin{array}{l}\text { Більшість ділових зустрічей, ведення переговорів, отримання } \\
\text { додаткових навичок переносяться в онлайн площину з використанням } \\
\text { різного роду відеосервісів, тому спеціалісти з організації даних } \\
\text { процесів викликають попит на ринку праці. }\end{array}$ \\
\hline SMM-менеджер & $\begin{array}{l}\text { Фахівець, який займається просуванням бізнесу, а саме компаній, } \\
\text { брендів і окремих осіб в соціальних медіа (Facebook, Instagram, } \\
\text { YоuTube, Twitter). До його завдань входить збільшення охоплення } \\
\text { сторінки клієнта, поліпшення сприйманого образу замовника, } \\
\text { комунікація з цільовою аудиторією. Переваги даної професії для } \\
\text { молодої людини: здійснення фрункціональних обов'язків з будь якої } \\
\text { точки світу, вільний графік роботи, фрінансова незалежність так як } \\
\text { оплата за надані послуги приходить не один раз на місяць }\end{array}$ \\
\hline
\end{tabular}

Джерело: сорормовано за даними [1]

На ряду з профресіями, які приведені в таблиці 1 також 3 новим вектором розвиваються й такі фрахові направленості як програміст, оператор call-центру, IT-консультант причому у всіх галузях національного господарства країни. На ринку праці на них зростає попит і вони стають найбільш затребувані, так як сьогодні більшість компаній та бізнес діджиталізується, повністю переходить на оцифрування даних, використовує онлайн ресурси для просування товару, продукції, послуг та забезпечує зв'язок з потенційними споживачами.

Популярність та затребуваність насьогодні у вікової категорії до 35 років $€$ й серед інтернет-профресій, сьогодні молодь хоче та вбачає перспективну з реалізації себе в блогерстві та просуванні ютуб каналів. Тож ТОП-6 інтернетпрофресій сучасності наведено на рис. 1.

На рисунку перелік просресій представлений в порядку їх ранжування від найпопулярнішої до менш затребуваної. Тому на першому місці перебуває блогер (блогінг), даний напрям сьогодні захопив весь інтернет простір і кожен, хто веде активну діяльність в Інстаграмі, Ютубі, Тік Тоці або іншій популярній соціальній мережі розвиває даний вид діяльності, адже це на сьогодні $є$ ефрективним каналом комунікації між продавцем товару, продукції чи послуги і його безпосереднім покупцем. Здійснення маркетингової діяльності в сучасних умовах ведення бізнесу без застосування такого напряму як блогінг вже реалізовувати стає не зовсім ефективно. Маючи достатньо широке коло підписників за рахунок реклами можна просувати свій бізнес або залучати інші бренди до співпраці і тим самим підвищувати рівень доходу.

Іншою затребуваною інтернет професією на сьогодні $€$ таргетолог, який займається координацією реклами в соціальних мережах. Основне завдання його полягає у визначенні цільової аудиторії та налаштування реклами, щоб вона працювала для тих споживачів, які мають попит на даний вид товару, продукції чи послуги. Представник даної профресії пови- 


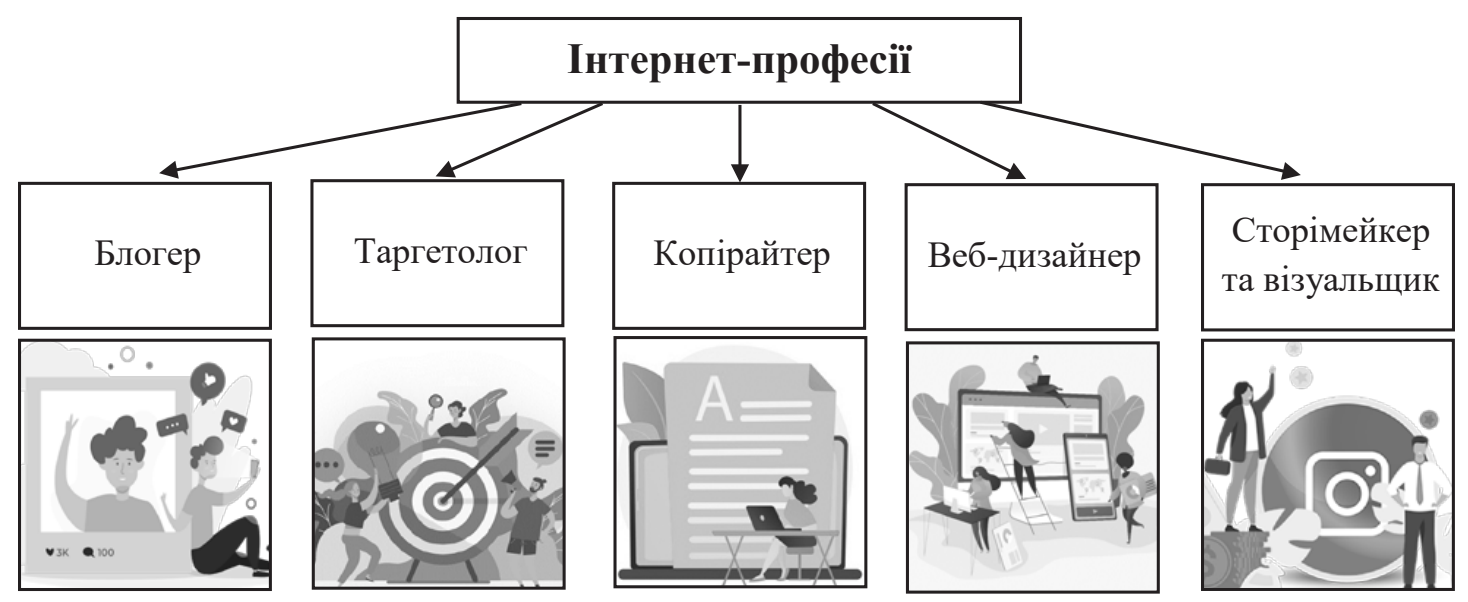

Рис. 1. Перелік інтернет-професій актуальних серед вікової групи до 35 років Джерело: сорормовано за даними [4]

нен володіти якісними характеристиками, до яких відносять аналітичний склад розуму, вміння планувати, швидко приймати рішення, орієнтуватися на платформах соціальних мереж, підходити до роботи з творчістю. Для еорективної реалізації своїх фрункцій блогер та таргетолог є взаємозв'язаними та бути у тісній взаємодії тим самим приносити користь один для одного.

Наступною за популярністю серед інтернет-професій $є$ копірайтер до функціональних обов'язків якого входять написання seoтекстів, email-розсилок, лендінгів, сценаріїв для відео, презентацій, книг, постів для соціальних мереж. Реалізувати себе людина за даним спрямуванням може на пошукових платорормах (Google) або на біржах (Advego, KWORK), де їх кваліфікація розширюється і вони починають займатися веб-райтингом або рерайтенгом, для цього їм надається чітко виписане технічне завдання, де прописано, яка повинна бути унікальність тексту, кількість ключових слів та структура тексту. На сьогодні дана профресія є досить популярною, послуги такого роду фахівців є затребуваними як для сайтів компаній, які починають просування свого бренду, так і для тих хто вже довгий час займається даним процесом.

Творчі та креативні особистості серед молоді можуть проявити себе в веб-дизайні, люди даної професії займаються створенням, дизайном сайтів, оформленням текстів, вдалим поєднанням кольорів, та комбінуванням важливих елементів. На ринку праці робота такого роду є досить високо оплачуваною, а фахівці досить затребуваними. Через наявну не значну кількість професіоналів в цій сорері конкуренція $€$ не занадто високою, що дає можливість для молодого фрахівця реалізувати себе в даному напрямі.

3 розвитком блогерства актуальності серед інтернет-професій набувають сторімейкери та візуальщики, які безпосередньо взаємодіють та потрібні блогеру. Їх завдання - це створення стрічки, яка зацікавить цільову аудиторію, сорормує попит товар, також вони створюють контент плани з метою збільшення охвату. Безпосередньо до функціональних обов'язків сторімейкера входить створення, дизайн та монтаж сторіз. Візуальщик - створює візуал (картинку), офрормлює їі, слідкує за дотримуванням правильних кольорових поєднань та стилю фротографій. В той же час сьогодні фрункції цих інтернет-професій успішно реалізовує і сам блогер, але все частіше він вдається до залучення даних спеціалістів з метою коригування профілю, покращення контенту та збільшення охвату для просування власного інтернет-бізнесу.

Отже, розвиток інтернет мережі та перехід бізнесу у онлайн простір сорормував виникнення низки нових професій, які зараз є затребуваними та розкривають перед віковою категорією до 35 років ряд унікальних можливостей для самореалізації і швидко переходять із захоплення в високооплачуваний заробіток. Для того щоб розуміти чому так все відбувається слід розглянути перелік основних фракторів, які сприяли виникненню та популярності інтернет-прооресій серед покоління у віковій категорії до 35 років і до них віднесено:

- світову пандемію коронавірусної хвороби COVID-19;

- зміну пріорітетності та зростання довіри до онлайн каналу комунікації;

- популярність торгових майданчиків, розташованих в інтернеті. 
В умовах пандемії відношення людей щодо використання онлайн профресій чи онлайн платформ для реалізації себе чи свого бізнесу воно змінилось, кожен переосмислив своє бачення щодо використання можливостей інтернет ресурсу та сорормував довіру до нього. На сьогодні в мережі інтернет можна замовити будь-який товар, продукцію і тобі його доставлять, знайти робоче місце, працювати дистанційно з іншого куточку світу, навчатися та підвищувати кваліфрікацію, світова мережа розкрила ряд можливостей для людей, які знаходячись будь де мають широкий перелік пропозицій для задоволення власного попиту.

Використання торгових майданчиків в інтернеті дозволяє компанії відмовитися від оренди комерційних приміщень під магазини. Тому сьогодні серед підприємців популярним $€$ відкриття інтернет-магазинів, а офрлайн торгові точки переходять на другий план або взагалі втрачають свою актуальність для просування бізнесу.

Експерти прогнозують також, що деякі профресії з тих, що зараз існують в науково-срантастичних книгах чи фрільмах на них попит може стати реальним вже у найближчий час: проектувальник дирижаблів, біоетик; інженер роботизованих систем, IT-медик, архітектор енергонульових магістралей, космогеолог тощо. Так, ми розуміємо, що за цим майбутнє і світові ринки праці поповняться й цими профресіями, але на сьогодні слід зупинити увагу на тому, а як зараз сорокусувати увагу та зацікавити молодих людей на тих професіях пропозиція яких наявна.

Ринок праці України до цього прийде можливо через років 30-50, але світ уже має потребу в фрахівцях, які зможуть сприяти у вирішенні проблеми збільшення чисельність населення планети та обмеженість природних ресурсів, які постійно зазнають скорочення, тому для цього потрібні будуть спеціалісти, які зможуть допомогти людству адаптуватись до таких змін та забезпечити продовольчу безпеку кожної з країн. Тому на сьогодні світ потребує розширення кількості спеціалістів агропоніки. Це фрахівець як в агрономії, так і в інженерії, які будуть адаптувати великі міста для вирощування сільськогосподарської продукції. Майбутній розвиток міст та всієї їх інфрраструктури не можливий без планувальників розумних міст, урбаністівекологів. Вони будуть займатися розбудовуванням міста з урахуванням новітніх технологій: встановлення дорожнього покриття 3 датчиками контролю стану дороги, а також «розумними» знаками, розміткою і системами відеоспостереження. Гостра потреба також на сьогодні стоїть і в інженерах 3 кліматології до функціональних обов'язків якого входить вивчення стану, встановлення закономірностей на пошук шляхів, які призведуть до послаблення чи запобігання негативним наслідкам змін клімату, що відбуваються, в фрахівцях 3 альтернативної енергетики, які розроблятимуть та обслуговуватимуть джерела чистої енергії. За прогнозами актуальність такої професії як утилізатор інформація теж буде користуватися попитом, адже кількість інорормації збільшується, вона потребує сортування, аналізу, упорядкування. Тому завданням таких фрахівців буде відслідковувати і знищувати непотрібну особисту чи профресійну інфрормацію [1].

Діджиталізація захоплює всі сорери господарювання, з'являється потреба у здійсненні підбору композитних матеріалів для виготовлення продукції, оволодіння технологіями 3 використанням 3D-друку (лазерної стереолітограсрії, селективного лазерного спікання, електронно-променевої плавки, наплавлення, ламінування тощо), на вирішення даних питань $є$ доцільним розширення класиорікатору профресій такими фрахівцями як інженер-композитник або оператор 3D-друку [1].

Тож, ринок праці XXI століття він швидко змінний, перелік профресій постійно оновлюється і вимагає від молодого фрахівця кросфуннкіональності у виконанні покладених на нього завдань. Сьогодні затребуваний працівник для роботодавця це той, який знає, де взяти інсрормацію, як їі адаптувати та застосувати у своїй діяльності, який може працювати на стику спеціальностей та одночасно виконувати ряд завдань, які кардинально відрізняються. Існує динаміка до зменшення термінів релевантності знань, які отримує молодий фрахівець коли закінчує заклад вищої освіти, крайня межа, коли знання спеціаліста $€$ актуальними це півроку, після чого їх слід оновлювати та повторювати даний процес систематично для підтримки своєї конкурентоздатності на ринку праці. Роботодавець в цьому плані зацікавлена сторона щодо підвищення кваліфрікації власних працівників, адже це виправдовується для нього більш ніж на 30\% і він отримує збільшення доходу фрірми. В той же час тенденція залишається поки не змінною, що віковій категорії до 35 років легше працевлаштуватися в містах-мільйонниках, де зосереджене виробництво, ссрормована від- 
повідна інфраструктура та ринок праці більш адаптований під нові зміни професій.

Висновки. Ринок праці сьогодні в Україні швидко змінний і кожному 3 суб'єктів до цих змін слід бути готовим як роботодавцям, так і тим хто шукає роботу. Безперечно ринок праці зазнає своїх змін завдяки розвитку технологій та IT-ссрери і завдяки роботизації та комп'ютеризації деякі завдання вже зараз виконуються краще ніж це роблять люди. Тому починаючи з вибору спеціальності слід розуміти перспективи працевлаштування після закінчення навчання, і які з профресій в цей період сорормують пропозицію та будуть затребуваними на ринку праці і зможуть задовільнити працівника своїм рівнем заробітку, перспективами кар'єрного зростання та роботодавця виходячи 3 його вимог. Також просресії майбутнього вони наштовхують покоління у віковій категорії до 35 років на те, що їм слід постійно навчатися протягом життя, проходити стажування, тренінги, бізнес-курси, підвищувати кваліфрікацію для того, щоб навички були актуальними та відповідали потребам часу.

\section{СПИСОК ВИКОРИСТАНИХ ДЖЕРЕЛ:}

1. Змінюйся або помри. До 2030 року зникне півсотні профресій URL: https://glavcom.ua/publications/ zminyuysya-abo-pomri-do-2030-roku-znikne-pivsotni-profesiy-natomist-zyavlyatsya-186-novih-520807.html (дата звернення: 19.02.2021).

2. Професії майбутнього: TOП-7 напрямків, що будуть популярними до 2020 року. URL: https://nuft.edu.ua/ job/korisno-znati/profes-majbutnogo-top-7-napryamkv-shho-budut-populyarnimi-do (дата звернення: 15.02.2021).

3. Стукан Т.М. Особливості зайнятості молоді в Україні. Міжнародний науковий журнал «Інтернаука». Серія : «Економічні науки». 2020. Випуск 7(39). С. 77-85. https://doi.org/10.25313/2520-2294-2020-7-6181

4. Стукан Т. Молодіжна політика: суть, основні принципи та стан реалізації в Україні. Таврійський науковий вісник. Серія : Економіка. 2020. Випуск 4. С. 125-131.

5. Топ-6 інтернет-профресій сучасності. URL: https://nizhyn.city/read/dosvid/109274/top-6-internet-profesijsuchasnosti (дата звернення: 15.02.2021).

6. Yurii Kyrylov, Natalia Kyrychenko, Tatyana Stukan and Hanna Zhosan. Formation of Enterprise. Management Strategies and Entrepreneurship Training. International Journal of Management. 2020. № 11(6). P. 793-800. URL: http://www.iaeme.com/MasterAdmin/Journal_uploads/ijm/VOLUME_11_ISSUE_6/IJM_11_06_067.pdf (дата звернення: 17.02.2020).

\section{REFERENCES:}

1. Profesii maibutnoho: TOP-7 napriamkiv, shcho budut populiarnymy do 2020 roku [Change or die. Fifty professions will disappear by 2030]. Available at: https://glavcom.ua/publications/zminyuysya-abo-pomri-do-2030-roku-znikne-pivsotni-profesiy-natomist-zyavlyatsya-186-novih-520807.html (accessed 19 February 2021).

2. Profesii maibutnoho: TOP-7 napriamkiv, shcho budut populiarnymy do 2020 roku [Professions of the future: TOP-7 areas that will be popular until 2020]. Available at: https://nuft.edu.ua/job/korisno-znati/profes-majbutnogo-top-7-napryamkv-shho-budut-populyarnimi-do (accessed 15 February 2021).

3. Stukan T. (2020) Osoblyvosti zainiatosti molodi v Ukraini [Features of youth employment in Ukraine]. Mizhnarodnyi naukovyi zhurnal «Internauka». Seriia: «Ekonomichni nauky», vol. 7(39), pp. 77-85. https://doi.org/ 10.25313/2520-2294-2020-7-6181

4. Stukan T. (2020) Molodizhna polityka: sut, osnovni pryntsypy ta stan realizatsii $\vee$ Ukraini [Youth policy: essence, basic principles and state of implementation in Ukraine]. Tavriiskyi naukovyi visnyk. Seriia: Ekonomika, vol. 4, pp. 125-131.

5. Top-6 internet-profesii suchasnosti [Top 6 online professions today]. Available at: https://nizhyn.city/read/dosvid/109274/top-6-internet-profesij-suchasnosti (accessed 15 February 2021).

6. Yurii Kyrylov, Natalia Kyrychenko, Tatyana Stukan, Hanna Zhosan (2020) Formation of Enterprise. Management Strategies and Entrepreneurship Training. International Journal of Management, no. 11(6), pp. 793-800. Available at: http://www.iaeme.com/MasterAdmin/Journal_uploads/ijm/VOLUME_11_ISSUE_6/IJM_11_06_067.pdf (accessed 17 February 2021). 